\title{
Agro-Morphological Characterization of Myrianthus Arboreus (P. Beauv) in Cote dIvoire
}

\author{
N'DRI Konan Ella*, GORE Bi Boh Nestor ${ }^{1}$ and AKAFFOU Doffou Sélastique ${ }^{1}$ \\ ${ }^{1}$ Department of Agronomy and Forestry \\ Jean Lorougnon Guédé University, BP 150 Daloa \\ Côte d'Ivoire
}

\begin{abstract}
The objective of this study is to evaluate the agro-morphologicals parameters of Myrianthus arboreus in five localities of the Côte d'Ivoire.

Seventy-five individuals of Myrianthus arboreus collected in five localities of Côte d'Ivoire (Abengourou, Adzopé, Daloa, Diabo and Zouan Hounien), have been evaluated agro-morphologically. Twelve characters selected from the descriptors of this plant were used in this study. Statistical analysis revealed a high variability between the individuals collected. But a higher value of parameters tested was recorded in Abengourou than Diabo. Positive correlations were observed between leaf, production parameters and between foliage and production parameters. Hierarchical Classification Analysis associated with Discriminant Factor Analysis showed that individuals tested were split in three groups with complementary characteristics. Among parameters tested leaves width and fruits full quarter's number were revealed as discriminating factors.
\end{abstract}

Keywords: Agro-morphological characterization, Genetic diversity, Plant, Myrianthus arboreus, Côte d'Ivoire.

\section{INTRODUCTION}

In Côte d'Ivoire, about 12 million hectares of forest were disappeared in less than forty years because of uncontrolled logging and agriculture [1]. In rural environment, deforestation is provoked a decreasing of cultivation places and a rarefaction of some alimentary plants such as Myrianthus arboreus. It belongs to Cecropiaceae family, M. arboreus is a dioecious plant presents in west and central Africa tropical forest.

This plant is prized because of its several nutritional and medicinal properties. Indeed, the young leaves of this plant are rich in iron, mineral and proteins [2]. Also, recent study conducted by [3] indicated that the root bark contains the most effective antioxidants for diabetes. In addition, [4] and [5] respectively highlighted the healing and anti-plastimodials properties of this species.

Outside, the both properties, the marketing of young leaves [6] and wood [7] of M. arboreus are a source of income for the populations. On local markets those leaves are sold by women about $1500 \mathrm{CFA} / \mathrm{Kg}$ and wood from this plant is sold about 1000 CFA/Kg per boot (Data not published). Because of several advantages of $M$. arboreus, since 2014 some trials about regeneration of this plant were undertaken [8]. During this experience, cuttings and seeds germination capacity were tested in order to it domestication by introducing them in cash crops (coffee and cacao) and subsistence crops [9].

Thus, basis on its socio-economic importance and threatened with extinction in forest, it is imperative that speedy solution be found. In this context, breeding of this plant could constitute a way to explore. But to implement such approach requires acquisition of debase on genetic diversity M. arboreus. To reach this objective some prospecting has been realized on five localities in Côte d'Ivoire in order to evaluate agro-morphological parameters of this species.

\section{MATERIAL AND METHODS}

\subsection{Study Sites}

Study was carried out in forest, fallow, on chard of cacao and cashew trees in five localities of Côte d'Ivoire (Table I). The study sites were chosen according to the use and ecology of plants. 
International Journal of Advances in Scientific Research and Engineering (ijasre), Vol 5 (8), August-2019

Table I. Geographic Location and Characteristics of Collection Sites [10-11]

\begin{tabular}{|c|c|c|c|c|}
\hline Cities & Coordinates & Vegetations & Temperature $\left({ }^{\circ} \mathrm{C}\right)$ & $\begin{array}{l}\text { Pluviometry } \\
\text { (mm/year) }\end{array}$ \\
\hline Abengourou & $6^{\circ} 43^{\prime} 47^{\prime \prime} \mathrm{N} ; 3^{\circ} 29^{\prime} 47^{\prime \prime} \mathrm{O}$ & Cocoa tree of orchard & 27.4 & $1000-1900$ \\
\hline Adzopé & $6^{\circ} 06^{\prime} 25^{\prime \prime} \mathrm{N} ; 3^{\circ} 51^{\prime} 36^{\prime \prime} \mathrm{O}$ & Fallow & 26.7 & $1200-2200$ \\
\hline Daloa & $6^{\circ} 54^{\prime} 28^{\prime \prime} \mathrm{N} ; 6^{\circ} 26^{\prime} 25^{\prime \prime} \mathrm{O}$ & Forest sacred & 26.2 & $1000-1900$ \\
\hline Diabo & $7^{\circ} 47^{\prime} 00^{\prime \prime} \mathrm{N} ; 5^{\circ} 11^{\prime} 00^{\prime \prime} \mathrm{O}$ & Cashew tree of orchard & 27 & $1000-1900$ \\
\hline Zouan Hounien & $6^{\circ} 55^{\prime} 00^{\prime \prime} \mathrm{N} ; 8^{\circ} 13^{\prime} 00^{\prime \prime} \mathrm{O}$ & Cocoa tree of orchard & 25.9 & $1600-2000$ \\
\hline
\end{tabular}

\subsection{Plant Material}

A total of 75 individuals of $M$. arboreus with age less than five years situated in five towns. Otherwise, 15 plants were collected per town.

\subsection{Collection of Data}

On each one of fifteen plants, twelves parameters were measured on the leaves and fruits of M. arboreus. A total of five parameters were measured on leaves : the number of lobes (NLo), length of the longest lobe (LLL), width of the longest lobe (WLL), leaf length (LLe), leaf width (LWi). Concerning to a fruit seven parameters were collected : the fruit weight (FrW), fruit quarters number (Fqn), fruit full quarters number (Ffq), fruit empty quarters number (Feq), seeds number (SNu), 100 seeds weight (HSW) and seeds weight (SWe).

\subsection{Statistical Analysis Method}

In order to check the diversity level of individuals collected, data obtained was submitted to some statistical analysis. It's about variance analysis (ANOVA), Principal component analysis (PCA), Hierarchical cluster analysis (HCA) and Discriminant Factorial Analysis (DFA). All analysis was with the software Statistical version 7.1. [12].

\section{RESULTS}

\subsection{Effect of Zone on Agro-morphological Parameters of M. Arboreus}

Analysis of variance showed that the origin of the individual has a significant effect on all variables. Individuals from Abengourou, Adzopé, Daloa and Zouan Hounien provided the longest lobes (LLL) and long leaves (LLe). For the width of the leaves (WLL), the wisest were recorded in the individuals of Abengourou and Adzopé against those of Diabo. As for the thickness of the lobes, the individuals of Abengourou gave the largest ones and those of Diabo, the smaller ones.

Regarding fruit production, the 100 seeds (HSW) and all the seeds (SWe) heavier per fruit are observed in the individuals of Abengourou against those of Diabo. As for the fruit quarters number (Fqn), fruit full quarters number (Ffq), fruit empty quarters number (Feq) and seeds number $(\mathrm{SNu})$ per fruit, the best performances are presented by individuals from Abengourou, Adzopé, Daloa and Zouan Hounien (Table II). 
International Journal of Advances in Scientific Research and Engineering (ijasre), Vol 5 (8), August-2019

Table II. Characteristics Individuals of M. Arboreus Studied in Different Cities

\begin{tabular}{|c|c|c|c|c|c|c|c|c|c|c|c|c|}
\hline \multirow{2}{*}{ Localities } & \multicolumn{12}{|c|}{ Agro-morphologicals parameters } \\
\hline & NLo & LLL (cm) & WLL (cm) & LLe (cm) & LWi (cm) & FrW (kg) & Fqn & Ffq & Feq & SNu & HSW (g) & SWe (g) \\
\hline Abengourou & $7 \pm 0^{a}$ & $50.26 \pm 4.31^{\mathrm{a}}$ & $20.42 \pm 2.44^{\mathrm{a}}$ & $96.31 \pm 8.41^{\mathrm{a}}$ & $67.53 \pm 6.96^{\mathrm{a}}$ & $1.05 \pm 0.07^{\mathrm{a}}$ & $140 \pm 4^{a}$ & $140 \pm 4^{\mathrm{a}}$ & $1 \pm 1^{\mathbf{b}}$ & $140 \pm 4^{\mathrm{a}}$ & $0.3 \pm 0.03^{\mathrm{d}}$ & $0.41 \pm 0.05^{\mathrm{c}}$ \\
\hline Adzopé & $7 \pm 0.46^{\mathrm{a}}$ & $49.41 \pm 3.67^{\mathrm{a}}$ & $19.44 \pm 1.74^{\mathrm{ab}}$ & $95.5 \pm 7.69^{\mathrm{a}}$ & $65.35 \pm 6.72^{\mathrm{a}}$ & $1.04 \pm 0.08^{\mathrm{a}}$ & $140 \pm 4^{\mathrm{a}}$ & $139 \pm 3^{a}$ & $1 \pm 1^{\mathbf{b}}$ & $139 \pm 3^{a}$ & $0.36 \pm 0.02^{\mathbf{b}}$ & $0.49 \pm 0.05^{b}$ \\
\hline Daloa & $7 \pm 0^{\mathbf{a}}$ & $46.54 \pm 4.13^{\mathrm{a}}$ & $18.21 \pm 2.58^{b}$ & $88.28 \pm 7.21^{\mathrm{a}}$ & $59.63 \pm 6.39^{b}$ & $1.02 \pm 0.08^{\mathrm{a}}$ & $139 \pm 3^{\mathrm{a}}$ & $138 \pm 4^{\mathrm{a}}$ & $1 \pm 1^{\mathbf{b}}$ & $138 \pm 4^{\mathrm{a}}$ & $0.33 \pm 0.02^{\mathrm{c}}$ & $0.43 \pm 0.03^{\mathbf{c}}$ \\
\hline Diabo & $7 \pm 0.46^{\mathrm{a}}$ & $38.91 \pm 8.18^{b}$ & $15.95 \pm 2.63^{\mathrm{c}}$ & $73.96 \pm 16.32^{b}$ & $51.77 \pm 8.89^{\mathrm{c}}$ & $1.01 \pm 0.06^{\mathrm{a}}$ & $129 \pm 4^{\mathbf{b}}$ & $126 \pm 4^{b}$ & $3 \pm 1^{\mathrm{a}}$ & $126 \pm 4^{\mathbf{b}}$ & $0.25 \pm 0.03^{\mathrm{e}}$ & $0.32 \pm 0.04^{d}$ \\
\hline Zouan Hounien & $7 \pm 0.35^{\mathrm{a}}$ & $48.74 \pm 5.2^{\mathrm{a}}$ & $18.67 \pm 3.07^{\text {ab }}$ & $95.08 \pm 12.83^{\mathrm{a}}$ & $65.04 \pm 9.17^{\text {ab }}$ & $1.04 \pm 0.07^{\mathrm{a}}$ & $139 \pm 4^{a}$ & $138 \pm 4^{\mathrm{a}}$ & $1 \pm 1^{b}$ & $138 \pm 4^{\mathrm{a}}$ & $0.41 \pm 0.02^{\mathrm{a}}$ & $0.54 \pm 0.04^{\mathrm{a}}$ \\
\hline $\boldsymbol{F}$ & $0.8 \mathrm{~ns}$ & $11.13 * * *$ & $6.55 * * *$ & $10.9 * * *$ & $10.15 * * *$ & $0.54 \mathrm{~ns}$ & $24.08 * * *$ & $33.29 * * *$ & $10.42 * * *$ & $33.29 * * *$ & $78.03 * * *$ & $58.39 * * *$ \\
\hline$P$ & 0.53 & 0 & 0 & 0 & 0 & 0.71 & 0 & 0 & 0 & 0 & 0 & 0 \\
\hline
\end{tabular}

Note: On the same column, the averages followed by the same letter are not significantly different (Fisher LSD test at 5\%).

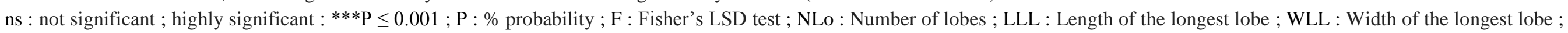

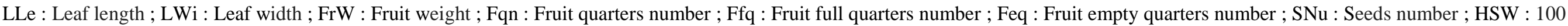
seeds weight and SWe : Seeds weight. 


\section{International Journal of Advances in Scientific Research and Engineering (ijasre), Vol 5 (8), August-2019}

\subsection{Relationship Between Agro-morphological Traits Studied in M. Arboreus}

Several significant correlations are observed between the measured variables (Table III).

Thus, intra-organ correlations indicate that the width of the longest lobe depends on the length of the longest lobe $(\mathrm{r}=+0.81)$.

The leaf length is determined by the length of the longest lobe $(r=+0.95)$ and the width of the longest lobe $(r=+0.77)$.

The leaf width is strongly and positively correlated with the length of the longest lobe $(r=+0.93)$, the width of the longest lobe ( $\mathrm{r}$ $=+0.84)$ and the leaf length $(\mathrm{r}=+0.93)$.

The fruit full quarters number is related to the fruit quarters number $(\mathrm{r}=+0.98)$.

The seeds number is thus determined by the fruit quarters number $(\mathrm{r}=+0.98)$ and the fruit full quarters number $(\mathrm{r}=+1)$.

The seeds weight is related to the fruit quarters number $(r=+0.73)$, the fruit full quarters number $(r=+0.73)$, the seeds number $(r$ $=+0.73)$ and the 100 seeds weight $(\mathrm{r}=+0.95)$.

At the inter-organ level, the fruit quarters number depends on the leaf length $(\mathrm{r}=+0.76)$ and the leaf width $(\mathrm{r}=+0.76)$, also on length of the longest lobe $(r=+0.75)$ and the width of the longest lobe $(r=+0.7)$.

The fruit full quarters number and the seeds number per fruit depend positively on the length of the longest lobe $(r=+0.75)$, the leaf length $(r=+0.75)$ and the leaf width $(r=+0.76)$.

Table III. Correlation Matrix Between 12 Variables Measured in 75 Individuals of M. Arboreus

\begin{tabular}{|c|c|c|c|c|c|c|c|c|c|c|c|c|}
\hline Characters & NLo & LLL & WLL & LLe & LWi & FrW & Fqn & Ffq & Feq & SNu & HSW & SWe \\
\hline NLo & 1 & & & & & & & & & & & \\
\hline LLL & 0.09 & 1 & & & & & & & & & & \\
\hline WLL & 0.06 & 0.81 & 1 & & & & & & & & & \\
\hline LLe & 0.13 & 0.95 & 0.77 & 1 & & & & & & & & \\
\hline LWi & 0.13 & 0.93 & 0.84 & 0.93 & 1 & & & & & & & \\
\hline FrW & 0.07 & 0.51 & 0.6 & 0.54 & 0.58 & 1 & & & & & & \\
\hline Fqn & 0.22 & 0.75 & 0.7 & 0.76 & 0.76 & 0.54 & 1 & & & & & \\
\hline Ffq & 0.21 & 0.75 & 0.68 & 0.75 & 0.76 & 0.51 & 0.98 & 1 & & & & \\
\hline Feq & -0.06 & -0.32 & -0.21 & -0.3 & -0.36 & -0.05 & -0.37 & -0.53 & 1 & & & \\
\hline SNq & 0.21 & 0.75 & 0.68 & 0.75 & 0.76 & 0.51 & 0.98 & 1 & -0.53 & 1 & & \\
\hline HSW & -0.04 & 0.55 & 0.42 & 0.55 & 0.53 & 0.28 & 0.62 & 0.63 & -0.35 & 0.63 & 1 & \\
\hline SWe & 0.04 & 0.62 & 0.52 & 0.65 & 0.62 & 0.38 & 0.73 & 0.73 & -0.36 & 0.73 & 0.95 & 1 \\
\hline
\end{tabular}

Note: Values in bold indicate correlations greater than or equal to 0.70 .

NLo : Number of lobes ; LLL : Length of the longest lobe ; WLL : Width of the longest lobe ; LLe : Leaf length ; LWi : Leaf width ; FrW : Fruit weight ; Fqn : Fruit quarters number ; Ffq : Fruit full quarters number ; Feq : Fruit empty quarters number ; $\mathrm{SNu}$ : Seeds number ; HSW : 100 seeds weight and SWe : Seeds weight.

\subsection{Principal Component Analysis (PCA)}

The Principal Component Analysis (PCA) was therefore performed on 10 of the 12 variables, that is without the fruit weight (FrW) and the fruit empty quarters number (Feq). This analysis indicated that eigenvalue axes greater than one (1) expressed, respectively, $6.45 \% ; 10.46 \%$ and $9.12 \%$ of the variance, a cumulative variance of $80.03 \%$ (Table IV).

Axis $1(62.45 \%)$ explains the length of the longest lobe (LLL), the width of the longest lobe (WLL), the leaf length (LLe), the leaf width (LWi), the fruit quarters number (Fqn), the fruit full quarters number (Ffq), the seeds number (SNu), the 100 seeds weight (HSW) and the seeds weight (SWe). All these variables are negatively related to the axis and this axis indicates that the most vigorous plants (vigor) are the most productive (fertility). None of the characters contributed to the formation of axis 2 which explains $10.46 \%$ of the total variance. Axis $3(9.12 \%)$ are essentially defined by the number of lobes (NLo) which is positively correlated to it. The analysis of this character involved in the formation of this axis revealed that it is characteristic of lobe abundance (Figure 1). 
International Journal of Advances in Scientific Research and Engineering (ijasre), Vol 5 (8), August-2019

Table IV. Matrix of Eigenvalues and Percentage of Variation Expressed by the Principal Axes of the PCA Relating to Ten Characters Analyzed in 75 Individuals of $M$. Arboreus

\begin{tabular}{llll}
\hline Main component & Axis $\mathbf{1}$ & Axis 2 & Axis 3 \\
\hline Own value & 7.49 & 1.26 & 1.09 \\
Total variance $(\%)$ & 62.45 & 10.46 & 9.12 \\
Cumulative total variance $(\%)$ & 62.45 & 72.91 & 82.03 \\
\hline NLo & -0.16 & -0.16 & $\mathbf{0 . 8 9} *$ \\
LLL & $\mathbf{- 0 . 9} *$ & -0.21 & -0.1 \\
WLL & $\mathbf{- 0 . 8 2} *$ & -0.36 & -0.13 \\
LLe & $\mathbf{- 0 . 9} *$ & -0.22 & -0.08 \\
LWi & $\mathbf{0 . 9 1} *$ & -0.24 & -0.06 \\
Fqn & $\mathbf{0 . 9 3} *$ & 0.04 & 0.15 \\
Ffq & $\mathbf{- 0 . 9 4 *}$ & 0.14 & 0.18 \\
SNu & $\mathbf{- 0 . 9 4 *}$ & 0.14 & 0.18 \\
HSW & $\mathbf{- 0 . 7 2} *$ & 0.48 & -0.27 \\
SWe & $\mathbf{- 0 . 8 1 *}$ & 0.38 & -0.18 \\
\hline
\end{tabular}

Note: * Significant values: variables that contribute the most to the formation of the axes.

NLo : Number of lobes ; LLL : Length of the longest lobe ; WLL : Width of the longest lobe ; LLe : Leaf length ; LWi : Leaf width ; Fqn : Fruit quarters number ; Ffq : Fruit full quarters number ; SNu : Seeds number ; HSW : 100 seeds weight and SWe : Seeds weight.

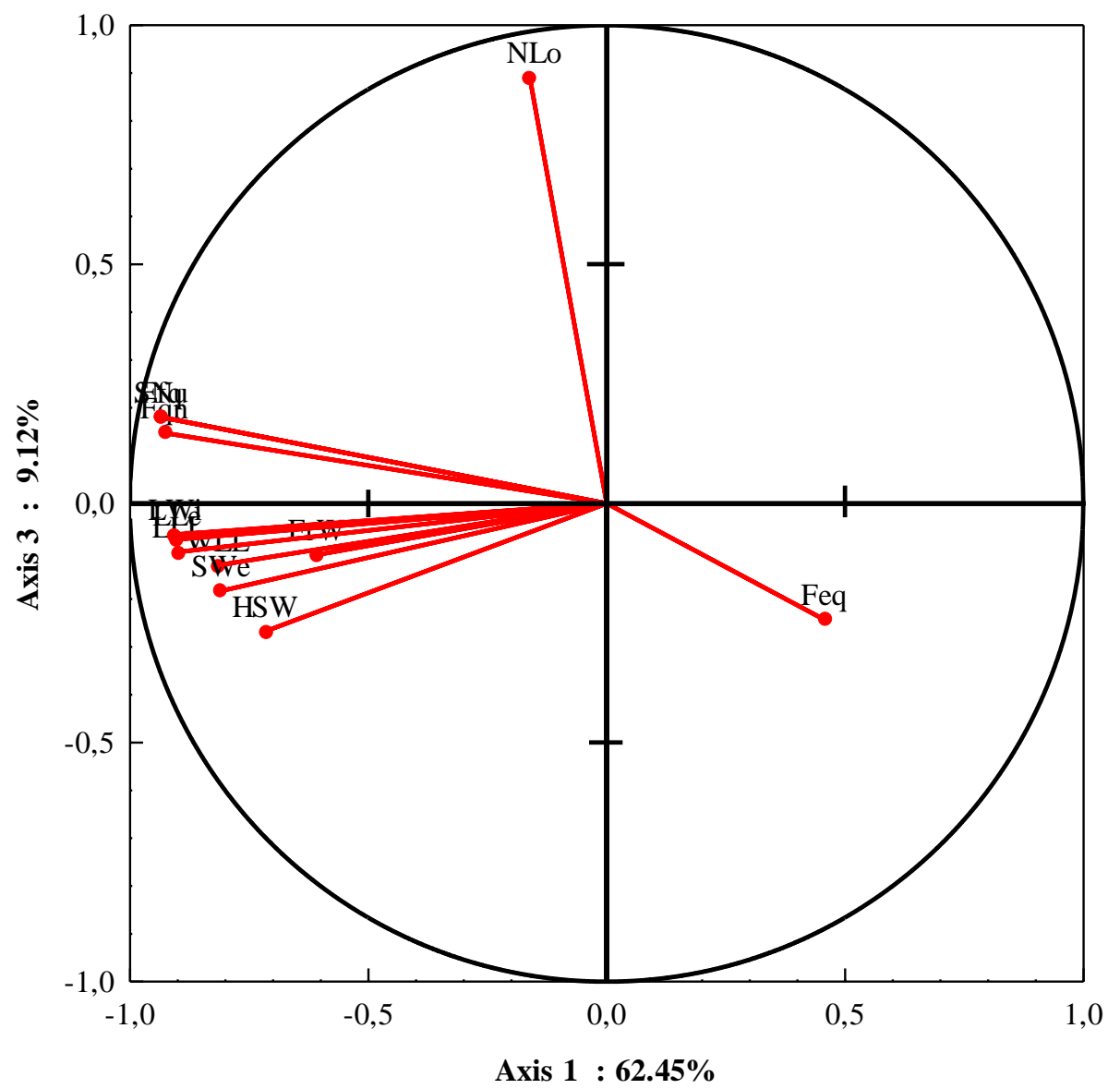

Figure 1. Distribution of variables in plane 1-3 revealed from ACP in 75 individuals of M. arboreus 


\subsection{Hierarchical Cluster Analysis (HCA)}

The hierarchical cluster analysis (HCA) analysis yielded 3 groups of individuals (Figure 2). Of the ten characters revealing a distinction between the three groups, nine characters (LLL, WLL, LLe, LWi, Fqn, Ffq, SNu, HSW, SWe) allowed a complete distinction (Table V). Thus, the distribution of the 75 individuals and their characteristics can be summarized as follows:

Group I: it is the group with the largest number of people (42 individuals, is $56 \%$ of the total workforce). This group is made up of individuals of various origins: Abengourou, Adzopé, Daloa, Diabo and Zouan Hounien. Individuals in this group have medium sized leaves and lobes. These individuals are characterized by the fruits quarters and fruits full quarters moderate with a number of intermediate seeds whose weight is less light.

Group II: the group with the smallest population (14 individuals), representing $18.67 \%$ of all individuals. It is composed of individuals from Abengourou, Adzopé, Daloa and Zouan Hounien. Individuals in this group have the best characteristics. The plants have large and ample leaves with important lobes of measures. These fruits contain quarter's number, full quarters and high seeds for heavy shields.

Group III: this group is made up of individuals from Abengourou, Adzopé, Daloa and Zouan Hounien, but mostly from Diabo. It represents $25.33 \%$ of the total workforce with 19 individuals. Individuals in this group have the most modest characteristics. This group contains plants with small leaves and lobes. The fruits borne by these plants have quarters, full quarters and seeds weak with a light weight seed.

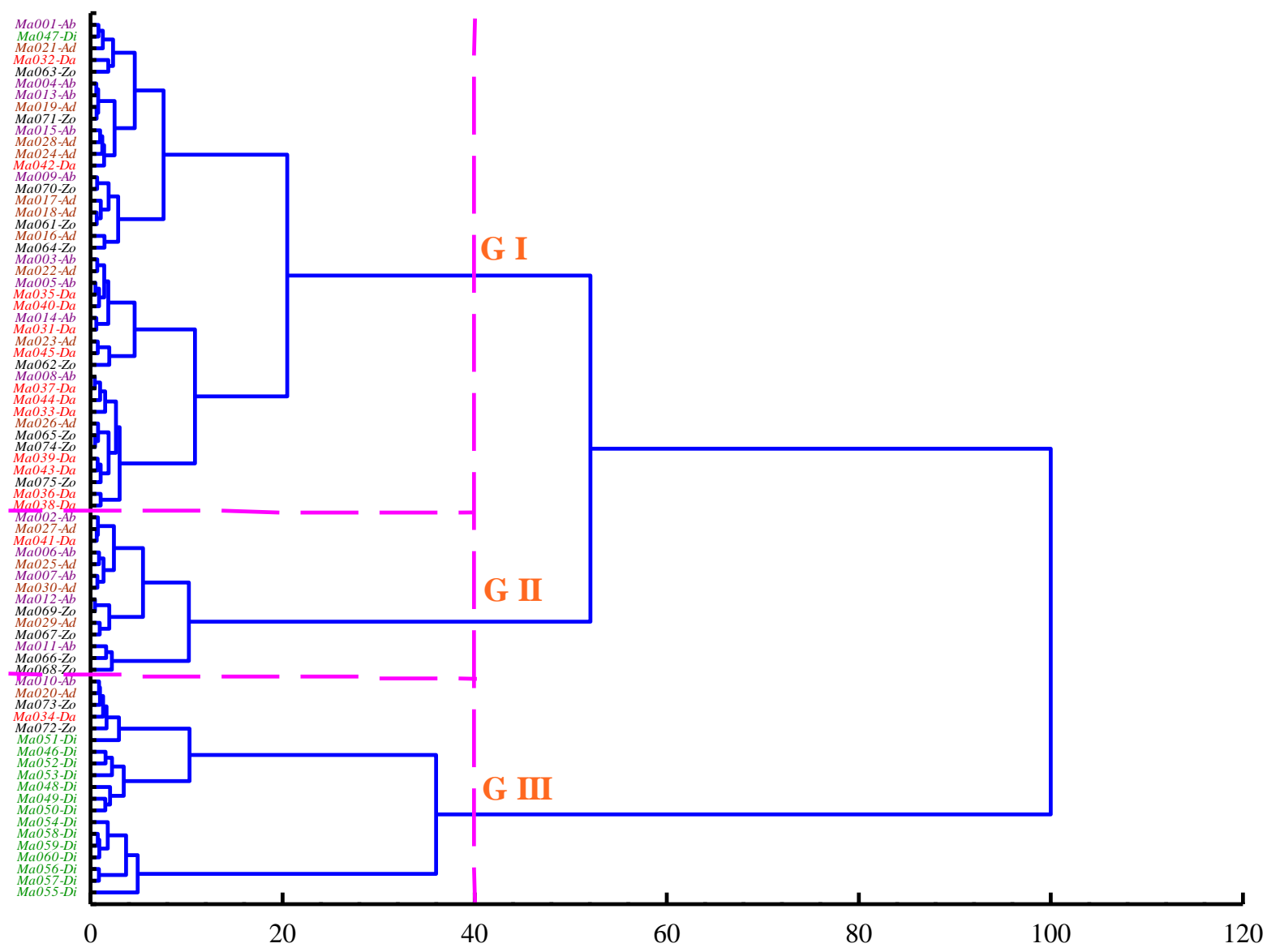

Figure 2. Dendrogram (UPGMA) of 75 Individuals of M. Arboreus Based on Euclidean Distances

G I: group I (42 individuals), G II: group II (14 individuals) and G III: group III (19 individuals) 
International Journal of Advances in Scientific Research and Engineering (ijasre), Vol 5 (8), August-2019

Table V. Main Characteristics of the Different Groups Formed by Ascending Hierarchical Classification

\begin{tabular}{|c|c|c|c|c|c|c|c|c|c|c|}
\hline Group-CAH & NLo & LLL (cm) & WLL (cm) & LLe (cm) & LWi (cm) & Fqn & Ffq & SNu & HSW (g) & SWe (g) \\
\hline Group I (N=42) & $7 \pm 0^{a}$ & $47.47 \pm 2.66^{\mathrm{b}}$ & $18.56 \pm 1.85^{\mathbf{b}}$ & $91.46 \pm 5.63^{b}$ & $62.31 \pm 4.7^{\mathbf{b}}$ & $139 \pm 3^{\mathbf{b}}$ & $138 \pm 2^{b}$ & $138 \pm 2^{b}$ & $0.34 \pm 0.04^{\mathrm{a}}$ & $0.46 \pm 0.05^{b}$ \\
\hline Group II (N=14) & $7 \pm 0^{\mathbf{a}}$ & $55.11 \pm 2.36^{\mathrm{a}}$ & $22.22 \pm 1.92^{\mathrm{a}}$ & $106.73 \pm 5.98^{a}$ & $75.04 \pm 4.31^{\mathrm{a}}$ & $143 \pm 3^{\mathrm{a}}$ & $142 \pm 3^{\mathrm{a}}$ & $142 \pm 3^{a}$ & $0.37 \pm 0.05^{\mathrm{a}}$ & $0.51 \pm 0.07^{\mathrm{a}}$ \\
\hline Group III (N=19) & $7 \pm 0^{\mathbf{a}}$ & $39.09 \pm 6.66^{c}$ & $15.76 \pm 2.27^{\mathrm{c}}$ & $73.74 \pm 13.18^{c}$ & $51.18 \pm 6,79^{\mathrm{c}}$ & $129 \pm 4^{\mathrm{c}}$ & $127 \pm 4^{\mathrm{c}}$ & $127 \pm 4^{\mathrm{c}}$ & $0.27 \pm 0.06^{\mathbf{b}}$ & $0.35 \pm 0.07^{\mathbf{c}}$ \\
\hline$F$ & $0.73 \mathrm{~ns}$ & $65.46 * * *$ & $43.2 * * *$ & $66.44 * * *$ & $84.02 * * *$ & $106.4 * * *$ & $119.1 * * *$ & $119.1 * * *$ & $20.29 * * *$ & $33.11 * * *$ \\
\hline $\boldsymbol{P}$ & 0.49 & 0 & 0 & 0 & 0 & 0 & 0 & 0 & 0 & 0 \\
\hline
\end{tabular}

Note: On the same column, the averages followed by the same letter are not significantly different (Fisher LSD test at 5\%), N: individuals number.

ns : not significant ; highly significant : ***P $\leq 0.001 ; \mathrm{P}: \%$ probability ; F : Fisher's LSD test ; NLo : Number of lobes ; LLL : Length of the longest lobe ; WLL : Width of the longest lobe ;

LLe : Leaf length ; LWi : Leaf width ; Fqn : Fruit quarters number ; Ffq : Fruit full quarters number ; SNu : Seeds number ; HSW : 100 seeds weight and SWe : Seeds weight. 
International Journal of Advances in Scientific Research and Engineering (ijasre), Vol 5 (8), August-2019

Principal component analysis (PCA) and hierarchical cluster analysis (HCA) allowed individuals to be grouped into three diverse groups. The discriminant factor analysis (DFA) made it possible to extract from the set of initial variables, a group of variables providing sufficient information for the discrimination of the groups defined above. Thus, on all ten quantitative variables, the DFA, through the $\lambda$-Wilk test, revealed two discriminant descriptors (Table VI). The hierarchy of discriminant variables is: leaf width (LWi) and fruit full quarters number (Ffq).

Table VI. Discriminant Analysis Based on Ten Agro-morphological Characters Analyzed in 75 Individuals of M. Arboreus

\begin{tabular}{cccccc}
\hline Variables & Wilks (Lambda) & $\boldsymbol{F}$ & $\boldsymbol{p}$ & Tolerance & 1-Tolerance $\left(\mathbf{R}^{2}\right)$ \\
\hline Ffq & 0.28 & 31.9 & 0 & 0.92 & 0.08 \\
LWi & 0.18 & 7.19 & 0.001 & 0.35 & 0.65 \\
\hline
\end{tabular}

Discriminant functions derived from variables to classify the units formed in the different groups were presented (Table VII). The first function (axis 1) has the greatest magnitude (4.45) and cumulates $92 \%$ of the total variance. It discriminates the fruit full quarters number (Ffq) that is positively correlated to this axis. The second discriminant function (axis 2) of weak magnitude (0.41) accumulates only $8 \%$ of the total diversity. Leaf width (LWi) is positively correlated.

Table VII. Percentage of Inertia and Definition of the Axes in DFA Performed on 75 Individuals of M. Arboreus

\begin{tabular}{lcc}
\hline Axes & $\mathbf{1}$ & $\mathbf{2}$ \\
\hline Own value & 4.45 & 0.41 \\
Inertia (\%) & 0.92 & 0.08 \\
Cumulative inertia (\%) & 0.92 & 100 \\
\hline NLo & -0.11 & -0.05 \\
LLL & 0.1 & 0.13 \\
WLL & -0.01 & 0.31 \\
LLe & 0.06 & -0.65 \\
LWi & 0.39 & $\mathbf{0 . 9 5 *}$ \\
Fqn & -0.09 & -0.22 \\
Ffq & $\mathbf{0 . 7 6 *}$ & -0.6 \\
SNu & 0 & 0 \\
HSW & -0.18 & -0.44 \\
SWe & 0.27 & 0.55 \\
\hline
\end{tabular}

NB: * Significant values: variables that contribute the most to the formation of the axes.

NLo : Number of lobes ; LLL : Length of the longest lobe ; WLL : Width of the longest lobe ; LLe : Leaf length ; LWi : Leaf width ; Fqn : Fruit quarters number ; Ffq : Fruit full quarters number ; SNu : Seeds number ; HSW : 100 seeds weight and SWe : Seeds weight.

In the discriminant factorial plane, the three groups formed by canonical axes 1 and 2 were presented (Figure 3). The group I is situated on either side of axis 1 . This function makes it possible to classify group I as a group characterized by plants with leaves width medium and whose fruits have a moderate full quarters number. Group II individuals are located in the positive part of axis 1. This group gathers individuals of leaves large for which the fruit full quarters number is high. Group III is located in the negative part of axis 1 . The individuals in this group have a low fruit full quarter's number and the leaves width is reduced. 


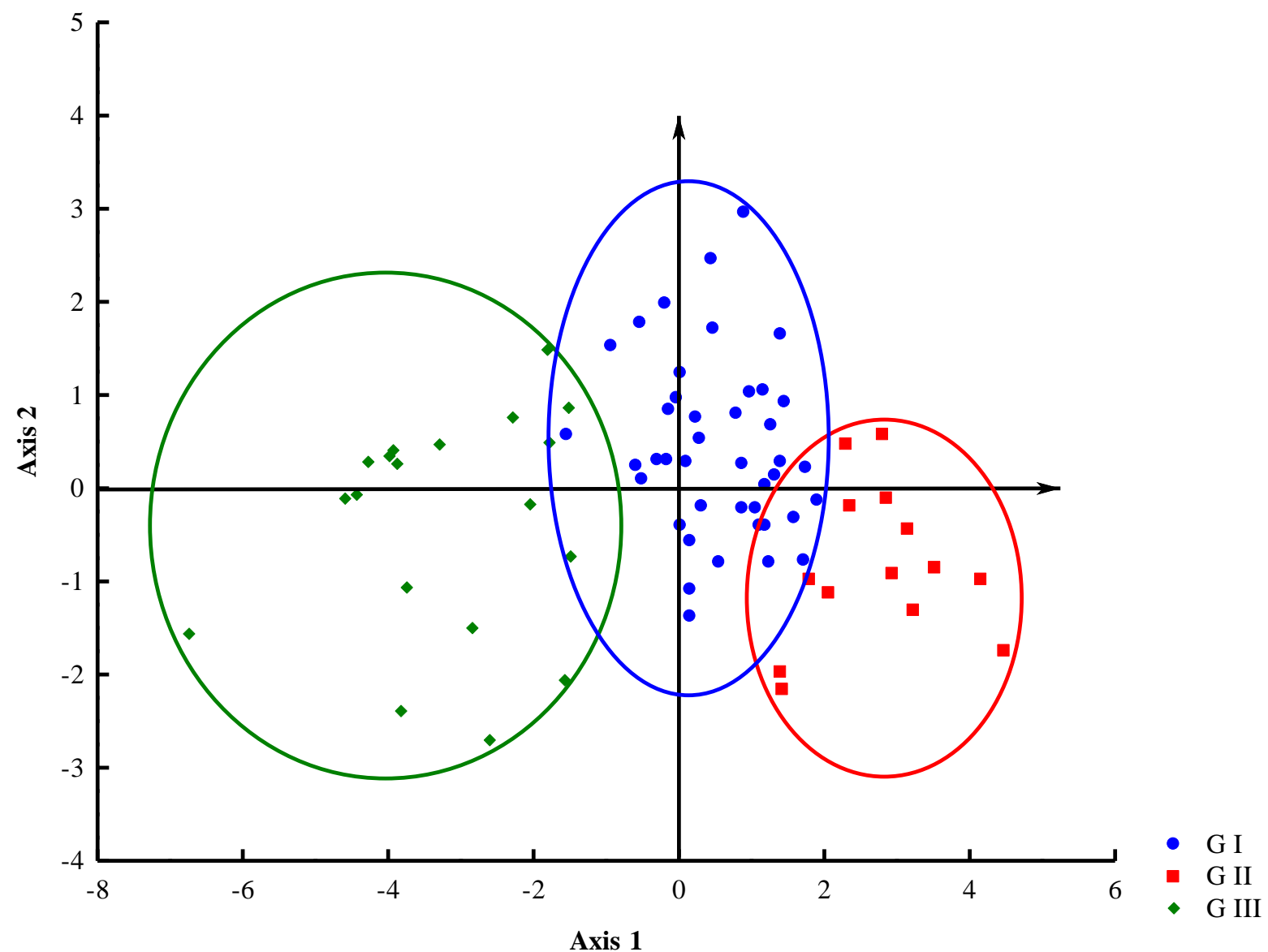

Figure 3. Representation of the groups of individuals of $M$. arboreus in the discriminating factorial plane formed by the canonical axes 1 and 2. G I: group I; G II: group II and G III: group III

An estimate of the percentage of classification of groups a priori has been established (Table VIII). The plants of group I only show the characteristics of this group (100\% correct classification). Of the 14 individuals in group II, 13 had the typical characteristics of group II (92.86\%) and 1 the characteristics of group I and group II. Of the 19 individuals forming group III, 17 have the typical characteristics of group III (89.47\%) and 2 the characteristics of group I and group III.

Table VIII. Relationship between groups 1, 2 and 3 from the cluster classification matrix

\begin{tabular}{ccccccc}
\hline \multirow{2}{*}{ Groups } & Percentage of classification $(\%)$ & \multicolumn{4}{c}{ Groups number } & Total \\
\cline { 3 - 6 } & & G I & G II & G III & \\
\hline G I & 100 & 42 & 0 & 0 & 42 \\
G II & 92.86 & 1 & 13 & 0 & 14 \\
G III & 89.47 & 2 & 0 & 17 & 19 \\
Total & 100 & 45 & 13 & 17 & 75 \\
\hline
\end{tabular}

G I: group I; G II: group II et G III: group III. 


\section{DISCUSSION}

Variance analysis showed that research areas have strongly influenced agro morphological parameters of M. arboreus. This highlights existence the largest variability of species in the collecting areas. A variability observed could be explain by the reproductive system of this plant. Indeed, a partial or total cross-pollinated lead to an important genetic diversity. Also, better value of twelve agro-morphological parameters has been recorded in Abengourou than Diabo. A difference of individuals performance observed in the both localities could be explained by the climate. Otherwise, climate has been an essential factor to define a diversity observed. A such variability result to the difference between pluviometry from localities [13].

Our result showed a positive and significatively correlation between length and width of lobes, length and width of leaf with quarters number, empty quarters and full quarters. Those four parameters linked (relating) to the leaf indicates leaf expanse better the importance leaf surface. Such predisposition of plant could allow him to pick up the sun's rays in order to realize photosynthetic activity. This means that plant production depends to leaves size [14]. It the case of sunflower, that some authors shown that leaf defoliation decrease production of this crop.

Principal Component Analysis (PCA) allowed defining agro-morphological diversity in three groups according to vigor, fertility and sterility. That result shows a diversity between individuals tested. This diversity observed could be explained by plants origin. The Hierarchical Cluster Analysis (HCA) and Discriminant Factorial Analysis (DFA) showed that individuals analysed were pooled in three groups. Which is in accordance with the PCA. This grouping was made independently of their origin. A similar result observed with the three analysis (PCA, HCA and DFA) means that individuals tested come from a common ancestor [15]. In additional, a result recorded during our study is similar to those of [16]. Indeed, they showed a clear existence between individuals of Citrullus lanatus come from Hungary and turkey.

\section{CONCLUSION}

A current study showed a great variability agro-morphological of 75 individuals collected in the five localities of Côte d'Ivoire. A higher value of leaf and production parameters was recorded in Abengourou than Diabo. Outside area of research, some positive correlations have been recorded between leaf, production parameters and between leaf and production parameters. Among parameters tested, leaf width and fruit full quarters number allowed to define three groups with complementary characteristics: fertility, vigor and sterility.

\section{THANKS}

We would like to express our deep gratitude to people of good will for financially contributing to the completion of this study. That Ms. Konan Ahou Honorine, Mr. Abbé Mambo Jules Paulin, Mr. Brou Dominique, Mr. Gompo Roger, Mr. Kouangoua Raphaël and Mr. Kouakou Claude Victorien who graciously offered us their availability for our data collection, find here our deepest recognition.

\section{REFERENCES}

[1] Aké Assi L., Boni D., Développement agricole et protection de la forêt : quel avenir pour la forêt ivoirienne ? Compte rendu de la XIIème réunion plénière de l’AETFAT symposium II, 1990, pp 169-176.

[2] Amata I A., Valeur nutritive des feuilles de Myrianthus arboreus : Un parcourir des végétaux. International Journal of Agricultural Research, 2010, 5: 576-581.

[3] Pierre K M S., Pierre H P., Tapjana., Etude du potentiel antioxydant des extractibles de Myrianthus arboreus. Centre de Recherche sur les Matériaux Renouvelables, Université Laval Quebec Canada. Note de recherche, $2015, V^{2} .2 N^{\circ} 4$.

[4] Agyare C., Ansah A O., Ossei P P S., Apenteng J A., Boakye Y D., Wound Healing and Anti-Infective Properties of Myrianthus arboreus and Alchornea cordifolia. Med chem, 2014, 4: 533-539.

[5] Memvanga P B., Tona G L., Mesia G K., Lusakibanza M M., Cimanga K., Antimalarial activity of medicinal plants from the Democratic Republic of Congo. Journal of ethnopharmacology, 2015, 169: 76-98.

[6] Kouamé N M T., Gnahoua G M., Arbres et lianes spontanées alimentaires du département de Gagnoa (centre-ouest de la Côte d' Ivoire). Bois et Forêts des Tropiques, 2008, $298: 65-75$.

[7] Ruffo C K., Birnie A., Tengnäs B., Les fruits comestibles du Cameroun. Journal of the Science of Food and Agriculture, 2002, 38: $67-72$.

[8] Akaffou D S., Kouassi K H., N'dah K., Evaluations of the Capacity and the Caracteristics of Germination of Myrianthus Arboreus (Cecropiaceae) by Cuttings Culture. International Journal of Advances in Scientific Research and Engineering (ijasre),

2018, 4 : 131-138. http://doi.org/10.31695/IJASRE.2018.32960 
International Journal of Advances in Scientific Research and Engineering (ijasre), Vol 5 (8), August-2019

[9] Akaffou D S., Kouassi K H., Agbeke M P., "Germinative Power Estimate and Germination Seeds Caracteristics of Myrianthus Arboreus (Cecropiaceae)". International Journal of Research Studies In Biosciences (Ijrsb), 2019, vol. 7, no. 3, pp. 27-35. http://Dx.Doi.org/10.20431/2349-0365.0703004

[10] Goula B T., Brou K., Brou T., Savane I., Vamoryba F., Bernard S., Estimation des pluies exceptionnelles journalières en zone tropicale: cas de la Côte d'Ivoire par comparaison des lois Log normale et de Gumbel. Journal des Sciences Hydrologiques, 2007, $52(1): 49-67$.

[11] Soro G E., Modélisation statistique des pluies extrêmes en Côte d'Ivoire. Thèse unique. Abidjan (Côte d'Ivoire): Université Nangui Abrogoua, 2011, 173 pages.

[12] StatSoft., STATISTICA, logiciel d'analyse de données, 2005, version 7.1.www.statsoft.fr.

[13] Zakaria K., Pauline B K., Romaric K N., Mahamadou S., Jean D Z., Caractérisation agro-morphologique du caya blanc (Cleome gynandra L.) de l'Ouest du Burkina Faso. International Journal of Innovation and Applied Studies, 2015, Vol. 11 No. 1, pp. 156-166.

[14] Schneiter A., Jones M., Hammond J J., Simulated hail research in sunflower: Defoliation. Agron. J., 1987, 79: $431-434$.

[15] Dane F., Liu J., Diversity and origin of cultivated and citron type watermelon (Citrullus lanatus). Genetic Resources and Crop Evolution, 2007, 54: 1255-1265.

[16] Szamosi C., Solmaz I., Sari N., Bársony C., Morphological characterization of Hungarian and Turkish watermelon (Citrullus lanatus (Thunb.) Matsum. et Nakai) genetic resources. Genetic Resources and Crop Evolution, 2009, 56: 1091-1105. 